\title{
Multi-enzyme cascade reaction in a miniplant two-phase- system: Model validation and mathematical optimization
}

\author{
Jens Johannsen ${ }^{1} \odot$ | Francesca Meyer ${ }^{1}$ | Claudia Engelmann ${ }^{2}$ | Andreas Liese $^{2}$ | \\ Georg Fieg $^{1}$ | Paul Bubenheim ${ }^{2}$ | Thomas Waluga ${ }^{1}$
}

${ }^{1}$ Institute of Process and Plant Engineering, Hamburg University of Technology, Hamburg, Germany

${ }^{2}$ Institute of Technical Biocatalysis, Hamburg University of Technology, Hamburg, Germany

\section{Correspondence}

Jens Johannsen, Institute of Process and Plant Engineering, Hamburg University of Technology, Am Schwarzenberg-Campus 4 (C), 21073 Hamburg, Germany.

Email: jens.johannsen@tuhh.de

\begin{abstract}
Biotechnological application of multiple enzymes in different phases for target compounds synthesis poses a significant challenge for industrial process development. At the same time, a growing demand for natural flavors and fragrances opens up possibilities for novel biotechnological processes to replace current chemical synthesis routes, with additional advantages such as avoiding harsh reaction conditions and toxic chemicals, and less by-products in the system. Within complex biotechnological processes, the key for unfolding their industrial application potential in bioprocess engineering lies in their mathematical modeling. In this contribution, a multi-enzyme cascade reaction in a two-phase system implemented in a miniplant-scale reactor setup is mathematically modeled for the example of the flavoring agent cinnamyl cinnamate. Using our validated model and a mathematical optimization tool based on a genetic algorithm, optimization runs are performed to demonstrate the potential of computer-aided process development for complex biotechnological processes.

\section{KEYWORDS}

cascade reactions, enzymes, mathematical modeling, optimization, process integration, simulation
\end{abstract}

\section{1 | INTRODUCTION}

The worldwide market for flavors and fragrances generates a 30 billion U.S.-dollars revenue volume per year, and grows at a $5 \%$ annual rate. ${ }^{1}$ Natural flavor production is of increasing importance, predominantly in Europe and North America. The U.S. Food \& Drug Administration defines natural flavors as those deriving their chemicals from animal or plant sources, as opposed to artificial flavors that use synthetic chemicals in the production process. ${ }^{2}$

Industrial biotechnology can fulfill naturality prerequisites through novel, sustainable processes. At the same time, its potential to replace current chemical synthesis routes remains controversial across different fields of study such as the production of specialty and fine chemicals. ${ }^{3-8}$ Here, a promising approach to the synthesis of flavors and fragrances is the development of in vitro multi-enzyme cascade reactions. ${ }^{8-12}$ These combine the benefits of enzymatically catalyzed reactions (e.g., high selectivity, mild reaction conditions) with the concept of process integration, thereby achieving benefits such as in situ cofactor regeneration, flexible design of new reaction routes, or the shift of unfavorable reaction equilibria. ${ }^{13,14}$ In literature, cascade reactions with up to 10 reaction steps and eight enzymes have been successfully established, albeit usually limited to the application in an aqueous phase. ${ }^{10,13}$ Few examples show the application in both aqueous and organic phases: they, however, make use of process integration (extraction steps) solely in order to enhance reaction turnover, without implementing additional reaction steps in the organic phase. ${ }^{15}$ In previous papers, our research group conclusively proved the applicability of multi-enzyme cascade reactions in a multiphase system for the production of specialty chemicals through the example of 
cinnamyl cinnamate with integrated cofactor regeneration and integrated intermediate extraction. ${ }^{11,16,17}$ As a consequent step toward productionscale process development, within this line of research we successfully implemented a continuous production process for the flavoring agent cinnamyl cinnamate in a $3 \mathrm{~L}$ miniplant reactor setup. ${ }^{11,18}$

Cinnamyl cinnamate is extracted as a natural component from Balsam of Peru, and used as a flavoring agent in cosmetic products and perfumes. ${ }^{19}$ Currently, two main chemical production processes are in use: styrene oxidative carbonylation with carbon monoxide, oxygen and aliphatic alcohols in the presence of palladium and sodium propionate, or cinnamic aldehyde synthesis in absolute ether with aluminum ethylate. ${ }^{19,20}$ Contrary to the conventional chemical approach, in this study we investigate an innovative production process for cinnamyl cinnamate that fits the criteria of both the U.S. Department of Health and Human Services ${ }^{2}$ and the European Union ${ }^{21}$ for labeling the product as a "natural flavor."

An important requirement to scale new production processes up for industrial application from an economic and/or ecological point of view is the possibility of a mathematical description of said process for continuous process control and development. ${ }^{822-24}$ However, due to the use of various enzymes and multiple phases, the mathematical description of complex biotechnological processes such as multienzyme cascade reactions constitutes an obstacle to biotechnological process development. ${ }^{8}$ Therefore, this study takes on the challenge of introducing a mathematical model to describe a complex biotechnological production process implemented in a miniplant. Our model is implemented in Aspen Custom Modeler ${ }^{\circledR}$ V8.8 (ACM, Aspen Technology, Inc.), and validated using experimental data obtained from the miniplant. In this study, we present the cinnamyl cinnamate-producing multi-enzyme cascade reaction sequence and discuss our mathematical model as well as experimental results for the miniplant. Furthermore, a mathematical optimization tool is used to perform simulation runs with the validated model, while simultaneously varying the process conditions to find optimal process operating windows, thereby proving the benefits of computer-aided process development in biotechnology.

\section{2 | PROCESS DESCRIPTION}

As the first step of process development toward a potential industrial application, the multidisciplinary studies and laboratory-scale analyses conducted by our research group and presented in previous peerreviewed papers, ${ }^{11,16}$ resulted in the in vitro multi-enzyme cascade reaction sequence for the production of cinnamyl cinnamate from cinnamyl aldehyde in a multiphase system (Figure 1).

An alcohol dehydrogenase $(A D H)$ converts cinnamyl aldehyde to cinnamyl alcohol in a buffer phase $(0.1 \mathrm{M}$ potassium phosphate buffer at $\mathrm{pH}$ 8.0) using the cofactor $\mathrm{NADH}$. Integrated cofactor regeneration within this cascade reaction sequence is ensured through addition of a formate dehydrogenase (FDH) converting formate to $\mathrm{CO}_{2}$ under $\mathrm{NAD}^{+}$ consumption. After in situ extraction of the intermediate cinnamyl alcohol with xylene as an organic solvent and cinnamic acid (CAC) addition, the lipase Novozym ${ }^{\circledR} 435$ performs an esterification reaction in the organic

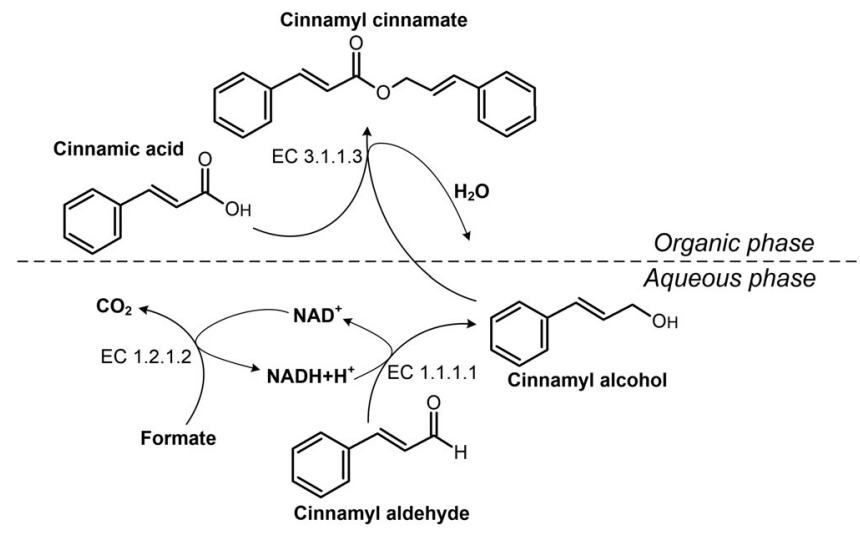

FIGURE 1 Multi-enzyme cascade reaction sequence for the production of cinnamyl cinnamate from cinnamyl aldehyde with integrated co factor regeneration and in situ intermediate extraction in a two-phase system ${ }^{11}$

phase to synthesize cinnamyl cinnamate and water. This process has successfully been established in both the laboratory and the miniplant. ${ }^{11}$

Figure 2 shows the flow chart of the miniplant used for this threeenzyme cascade reaction. The two cofactor-coupled dehydrogenases are immobilized on silica particles according to Engelmann et al $^{16}$ and placed in a two-liter continuously operated stirred tank reactor tempered to $30^{\circ} \mathrm{C}$, equipped with a SpinChem ${ }^{\circledR}$ RBR S2 rotating bed reactor (SpinChem AB, Umeå, Sweden), spinning at $400 \mathrm{rpm}$ (Figure 2a). This reactor type offers the benefit of easily exchanging batches of immobilized enzymes without much construction work, while at the same time ensuring thorough mixing of the aqueous phase. A buffer tank is used for the organic phase and for CAC feeding (Figure $2 b$ ). According to the principles of process integration, the extraction step connects both phases as they are mixed and immediately separated in one apparatus, a CINC CS 50 extractive centrifuge (CINC Deutschland GmbH \& Co. KG, Brakel, Germany) (Figure 2c). For the final esterification reaction step, the CAC- and alcohol-loaded xylene phase is subsequently pumped through a fixed bed reactor, containing $12.8 \mathrm{~g}$ of Novozym ${ }^{\circledR} 435$ and tempered to $60^{\circ} \mathrm{C}$ according to the enzyme provider's information (Figure $2 \mathrm{~d}$ ). Since the lipase is commercially available and proved to be stable for extended times of operation, ${ }^{23,25}$ no exchange of lipase batches was necessary. Therefore, the application of a simple-tooperate and well-established fixed bed reactor was preferred over an additional SpinChem ${ }^{\circledR}$ reactor in the organic phase.

\section{3 | MATHEMATICAL MODEL}

In order to simulate the multi-enzyme cascade reaction sequence in the miniplant, a customized mathematical model is developed and solved in Aspen Custom Modeler ${ }^{\circledR}$ V8.8 (Aspen Technology, Inc.) using an equation-oriented approach for simulating. As shown in Figure 3, this model is divided into three sub-models: aqueous phase, phase interface, and organic phase. These sub-models are connected through differential mass balance equations for each component. The reaction kinetics used for the mathematical modeling of each enzyme have been obtained through kinetic measurements. 


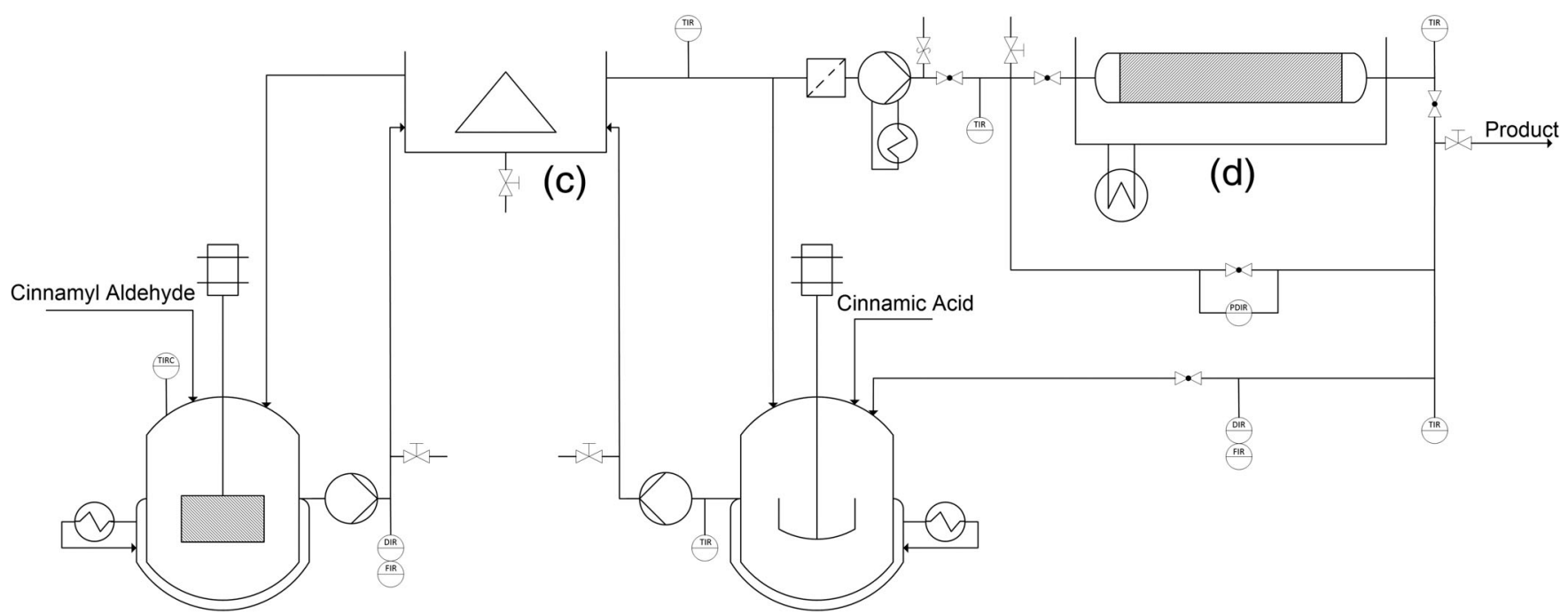

(a)

(b)

FIGURE 2 Flow chart of the miniplant consisting of a continuously stirred tank reactor (CSTR) (a), a buffer tank (b), an extractive centrifuge (c) and a fixed bed reactor $(d)^{11}$

FIGURE 3 Schematic structure of the model for the miniplant as implemented in Aspen Custom Modeler ${ }^{\circledR}$

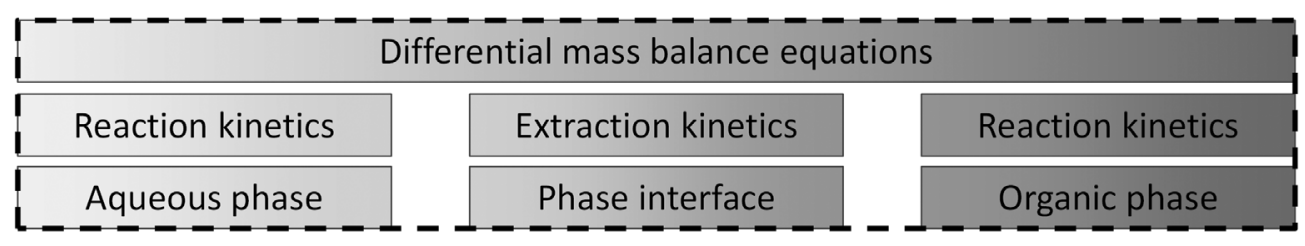

\subsection{Aqueous phase}

A bi-bi mechanism with competitive inhibition for both the ADHcatalyzed reaction of cinnamyl aldehyde (CAL) to cinnamyl alcohol $(\mathrm{COH})$ and the $\mathrm{FDH}$-catalyzed reaction of formate to $\mathrm{CO}_{2}$ are implemented in the model according to initial rate measurements as presented by Engelmann et al, ${ }^{26}$ describing the $\mathrm{ADH}$ reaction rate according to Equation (1) and the FDH reaction rate according to Equation (2). The corresponding values for the constants are listed in Table 1.

$$
\begin{aligned}
v_{\mathrm{ADH}}= & \frac{v_{\mathrm{max}, \mathrm{ADH}} \cdot([\mathrm{CAL}] \cdot[\mathrm{NADH}])}{K_{\mathrm{m}, \mathrm{CAL}} \cdot K_{\mathrm{m}, \mathrm{NADH}+\mathrm{H}^{+}} \cdot\left(1+\frac{[\mathrm{COH}]}{K_{\mathrm{l}, \mathrm{COH}}}\right)+K_{\mathrm{m}, \mathrm{NADH}} \cdot[\mathrm{CAL}]} \\
& +K_{\mathrm{m}, \mathrm{CAL}} \cdot[\mathrm{NADH}] \cdot\left(1+\frac{[\mathrm{COH}]}{K_{\mathrm{l}, \mathrm{COH}}}\right)+[\mathrm{CAL}] \cdot[\mathrm{NADH}] \\
V_{\mathrm{FDH}}= & \frac{V_{\mathrm{max}, \mathrm{FDH}} \cdot([\mathrm{NAD}+] \cdot[\text { formate }])}{K_{\mathrm{m}, \mathrm{NAD}} \cdot K_{\mathrm{m}, \text { formate }} \cdot\left(1+\frac{[\mathrm{NADH}]}{K_{\mathrm{l}, \mathrm{NADH}}}\right)+K_{\mathrm{m}, \text { formate }} \cdot\left[\mathrm{NAD}^{+}\right]} \\
+ & K_{\mathrm{m}, \mathrm{NAD}} \cdot[\text { formate }] \cdot\left(1+\frac{[\mathrm{NADH}]}{K_{\mathrm{l}, \mathrm{NADH}}}\right)+[\text { formate }] \cdot\left[\mathrm{NAD}^{+}\right]
\end{aligned}
$$

The kinetic Equations (1) and (2) describe the reaction rates of free enzymes. During the immobilization process, a decrease in enzyme activity can be observed and is described by an efficiency
TAB LE 1 Kinetic parameters of the ADH and FDH catalyzed reactions in the aqueous phase

\begin{tabular}{lll}
\hline Parameter & Unit & Value \\
\hline$v_{\text {max,ADH }}$ & $\left(\mathrm{U} / \mathrm{mg}_{\text {enzyme }}\right)$ & $3.49 \pm 1.53$ \\
\hline$K_{\mathrm{m}, \mathrm{CAL}}$ & $(\mathrm{mM})$ & $0.39 \pm 0.20$ \\
\hline$K_{\mathrm{m}, \mathrm{NADH}}$ & $(\mathrm{mM})$ & $0.08 \pm 0.07$ \\
\hline$K_{\mathrm{l}, \mathrm{COH}}$ & $(\mathrm{mM})$ & $0.04 \pm 0.03$ \\
\hline$v_{\mathrm{max}, \mathrm{FDH}}$ & $\left(\mathrm{U} / \mathrm{mg}_{\text {enzyme }}\right)$ & $0.46 \pm 0.07$ \\
\hline$K_{\mathrm{m}, \mathrm{NAD}}{ }^{+}$ & $(\mathrm{mM})$ & $0.04 \pm 0.02$ \\
\hline$K_{\mathrm{m}, \text { formate }}$ & $(\mathrm{mM})$ & $10.14 \pm 6.67$ \\
\hline$K_{\mathrm{I}, \mathrm{NADH}}$ & $(\mathrm{mM})$ & $0.27 \pm 0.42$ \\
\hline
\end{tabular}

factor $\eta_{\text {eff. }}{ }^{16}$ Remaining enzyme activity after immobilization for both $\mathrm{FDH}$ and $\mathrm{ADH}$ was determined to be $4 \%$ of the respective free enzyme activity. Additionally, as described in literature, a loss of activity over time was observed for the $A D H$, significantly affecting the reaction rates. ${ }^{27}$ This time-dependent activity loss reaches values up to $68 \%$ and is described in the model by the deactivation factor $f_{\text {deac }}$. The effective reaction rates for the dehydrogenases can be obtained after multiplying the respective kinetic equations with the enzyme mass, while considering the aforementioned activity losses, resulting in Equation (3) for the $\mathrm{ADH}$ and Equation (4) for the FDH respectively. 


$$
\begin{gathered}
v_{\text {eff,ADH }}=f_{\text {deac }} \cdot \eta_{\text {eff,ADH }} \cdot v_{\mathrm{ADH}} \cdot m_{\mathrm{ADH}} \\
v_{\mathrm{eff}, \mathrm{FDH}}=\eta_{\mathrm{eff}, \mathrm{FDH}} \cdot v_{\mathrm{FDH}} \cdot m_{\mathrm{FDH}}
\end{gathered}
$$

As expected due to the application of a phosphate buffer, ${ }^{28}$ experimental results showed auto-oxidation of the cofactor $\mathrm{NADH}$ over time, as previously reported in literature. ${ }^{29,30}$ In order to model the reaction system as precisely as possible, the auto-oxidation of $\mathrm{NADH}$ was measured at wavelengths of $\lambda_{1}=340 \mathrm{~nm}$ and $\lambda_{2}=292 \mathrm{~nm}$ in a time range of $48 \mathrm{hr}$ using a VWR ${ }^{\mathrm{TM}} \mathrm{UV}-1600 \mathrm{PC}$ Spectrophotometer. Additionally, absorption values at $\lambda_{3}=260 \mathrm{~nm}$ increased analogous to $\mathrm{NADH}$-oxidation during these experiments, indicating that $\mathrm{NADH}$ is oxidized to $\mathrm{NAD}^{+}$. In our mathematical model it is therefore assumed, that $\mathrm{NADH}$ auto-oxidizes to $\mathrm{NAD}^{+}$. The resulting $\mathrm{NADH}-$ oxidation for this system is described through a function of exponential decay as shown in Equation (5). The empirical constants shown in Equation (5) are the result of fitting the experimental data with a coefficient of determination of 0.98 , resulting in a factor constant of $0.66 \pm 0.07$ and a constant in the exponent of $-0.00179 \pm 0.00033$.

$$
\frac{d[\mathrm{NADH}]_{\text {oxidation }}}{d t}=[\mathrm{NADH}]_{t-1} \cdot\left(1-0.66 \cdot e^{-0.00179 \cdot t}\right)
$$

Laboratory-scale experiments for the determination of enzymatic reaction kinetics required a broad range of concentrations as starting conditions, thereby showing precipitation of the components CAC, aldehyde, and alcohol from the liquid phase at experimental settings with high concentrations. Especially the low water saturation concentration of CAC led to precipitation. In order to be able to simulate substance precipitation and dissolution in the aqueous phase and thus achieve a higher model depth for the miniplant, a storage term $\dot{n}_{\text {precipitation, } i}$ is introduced for any given component $\mathrm{i}$. In every time step of the dynamic simulation, the concentration of each component in the aqueous phase is compared to the saturation concentration of that same component. If the concentration exceeds the saturation concentration, the overlap is stored in the storage term, from which it can dissolute again at lower concentrations.

The mass balance of each component in the aqueous phase is therefore described through differential equations in dependency on the reactions of the respective enzymes, the feed streams, mass transfer to the organic phase, and the precipitated amount in each time step. Equation (6) shows the generalized form of the mass balance for any given component $i$ in the volume specific form. Equations (7) and (8) show the modified forms of the mass balance for the cofactors $\mathrm{NADH}$ and $\mathrm{NAD}^{+}$respectively, considering the auto-oxidation of $\mathrm{NADH}$ instead of the non-existing precipitation of the cofactors.

$$
\begin{gathered}
\frac{d[i]}{d t}= \pm v_{\text {eff,FDH }} \pm v_{\text {eff,ADH }}+\dot{n}_{\text {feed }, i}-\dot{n}_{\text {transfer }, i} \pm \dot{n}_{\text {precipitation }, i} \\
\frac{d[\mathrm{NADH}]}{d t}=+v_{\text {eff,FDH }}-v_{\text {eff,ADH }}+\dot{n}_{\mathrm{NADH}, \text { feed }}-\dot{n}_{\mathrm{NADH}, \text { transfer }}-\dot{n}_{\mathrm{NADH}, \text { oxidation }}
\end{gathered}
$$

$$
\frac{d\left[\mathrm{NAD}^{+}\right]}{d t}=-v_{\mathrm{eff}, \mathrm{FDH}}+v_{\mathrm{eff}, \mathrm{ADH}}+\dot{n}_{\mathrm{NAD}^{+}, \text {feed }}-\dot{n}_{\mathrm{NAD}^{+}, \text {transfer }}+\dot{n}_{\mathrm{NADH}, \text { oxidation }}
$$

\section{2 | Phase interface}

The mass transfer at the phase interface is important, in that it affects the concentrations of all components in both phases, thereby influencing all three enzymatic reactions. Experimental results show that the mass transfer rate in the centrifuge is significantly higher than the reaction rates of all three enzymes in the reactors (see Supporting Information). Therefore, the assumption of instantaneous mass transfer seems reasonable ${ }^{31}$ : this leads to a concentration distribution between the two phases according to the partition coefficient for each component $i$ as described according to Equation (9).

$$
P_{i}=\frac{[i]_{\text {organic phase }}}{[i]_{\text {aqueous phase }}}
$$

The partition coefficients were determined in concentration ranges of 0.02-1,000 mM in triplets and are listed in Table 2. As expected, the partition coefficients proved to be concentration-independent.

Analogous to the aqueous phase, component precipitation is described with storage terms for the extractive centrifugation step. Additionally, during this step, each one of the two phases is saturated with its counterpart. The temperature in the extractive centrifuge influences the productivity of the final reaction step by affecting water saturation concentration in the organic phase, as described in previous studies. ${ }^{11}$ Therefore, the linear temperature-dependent water saturation concentration of the organic phase is implemented in the model according to Equation (10). ${ }^{11}$

$$
W_{\text {water- } \text { organic }}=0.0015 \cdot T_{\text {centrifuge }}+0.0081
$$

\section{3 | Organic phase}

The immobilized-lipase-filled fixed bed reactor for the esterification reaction is modeled as a cascade of $\sigma$ CSTR reactors ${ }^{22}$ according to

TABLE 2 Partition coefficients of all components in the two phase system

\begin{tabular}{llc} 
Component & Unit & Partition coefficient \\
\hline $\mathrm{CAC}$ & $(-)$ & 23.3 \\
$\mathrm{CAL}$ & $(-)$ & 7 \\
$\mathrm{CCl}$ & $(-)$ & 1,000 \\
$\mathrm{COH}$ & $(-)$ & 5.6 \\
\hline $\mathrm{NAD}$ & $(-)$ & 0 \\
\hline $\mathrm{NADH}$ & $(-)$ & 0 \\
\hline
\end{tabular}


TABLE 3 Kinetic parameters of the lipase catalyzed esterification reaction in the organic xylene phase

\begin{tabular}{lll}
\hline Parameter & Unit & Value \\
\hline$V_{\text {max,lipase,forward }}$ & $\left(\mathrm{U} / \mathrm{mg}_{\text {enzyme }}\right)$ & $6.3 \pm 1.2$ \\
$V_{\text {max,lipase,reverse }}$ & $\left(\mathrm{U} / \mathrm{mg}_{\text {enzyme }}\right)$ & $14.8 \pm 2.8$ \\
\hline$K_{\mathrm{m}, \mathrm{CAC}}$ & $(\mathrm{mM})$ & $1.4 \pm 0.3$ \\
\hline$K_{\mathrm{m}, \mathrm{COH}}$ & $(\mathrm{mM})$ & $2.8 \pm 0.5$ \\
\hline$K_{\mathrm{m}, \mathrm{H} 2 \mathrm{O}}$ & $(\mathrm{mM})$ & 0 \\
$K_{\mathrm{m}, \mathrm{CCl}}$ & $(\mathrm{mM})$ & $0.8 \pm 0.2$ \\
\hline$K_{\mathrm{l}, \mathrm{CAC}}$ & $(\mathrm{mM})$ & $13.7 \pm 2.6$ \\
$K_{\mathrm{l}, \mathrm{CAC}}^{\prime}$ & $(\mathrm{mM})$ & $1.4 \pm 0.3$ \\
\hline$K_{\mathrm{l}, \mathrm{H} 2 \mathrm{O}}$ & $(\mathrm{mM})$ & $252.9 \pm 48.1$ \\
\hline$K_{\mathrm{eq}}$ & $(-)$ & $2.6 \pm 0.5$ \\
\hline
\end{tabular}

Equation (11). For each CSTR $j$, a mole flow $\dot{n}_{\text {CSTR,j,i }}$ is defined which contains the concentrations of all cinnamyl derivatives for the subsequent CSTR $j+1$. A deactivation of Novozym ${ }^{\circledR} 435$ was not noted over time; therefore no time-dependent deactivation constant is implemented. Due to temperature variations between the extraction step and the fixed bed reactor, a temperature-dependent concentration change is implemented through a temperature-dependent change in density $\rho$ of the organic phase. Since component precipitation in the organicphase cycle was not noted due to the high saturation concentrations of the cinnamyl derivatives, no storage term is implemented in this submodel. Based on progress curve analyses described by Engelmann et al, ${ }^{26}$ the lipase reaction rate is described according to a bi-bi mechanism with substrate excess inhibition of CAC for the present reaction system. Equation (12) shows the lipase reaction rate as implemented in the model, and the corresponding parameters are described in Table $3{ }^{32}$

$$
\begin{aligned}
& \dot{n}_{C S T R, j, i}=\dot{n}_{C S T R, j-1, i} \pm v_{\text {lipase }} \cdot \frac{m_{\text {lipase }}}{\sigma} \\
& v_{\text {lipase }}=\frac{v_{\text {max,lipase,forward }} \cdot\left([\mathrm{COH}] \cdot[\mathrm{CAC}]-\frac{\left[\mathrm{H}_{2} \mathrm{O}\right] \cdot[\mathrm{CCl}]}{K_{\mathrm{eq}}}\right)}{K_{\mathrm{l}, \mathrm{CAC}} \cdot K_{\mathrm{m}, \mathrm{COH}}+K_{\mathrm{m}, \mathrm{COH}} \cdot[\mathrm{CAC}] \cdot\left(1+\frac{[\mathrm{CAC}]}{K_{\mathrm{l}, \mathrm{CAC}}^{\prime}}\right)+} \\
& K_{\mathrm{m}, \mathrm{CAC}} \cdot[\mathrm{COH}]+[\mathrm{COH}] \cdot[\mathrm{CAC}]+\frac{v_{\text {max }, \text { lipase,forward }}}{v_{\text {max,lipase, reverse }}} \cdot \frac{K_{\mathrm{m}, \mathrm{H} 2 \mathrm{O} \cdot[\mathrm{CCl}]}}{K_{\text {eq }}}+ \\
& \frac{v_{\text {max,lipase,forward }}}{v_{\text {max,lipase,reverse }}} \cdot \frac{K_{\mathrm{m}, \mathrm{CCl}} \cdot\left[\mathrm{H}_{2} \mathrm{O}\right]}{K_{\text {eq }}}+\frac{v_{\text {max,lipase,forward }}}{v_{\text {max,lipase,reverse }}} \cdot \frac{[\mathrm{CCl}] \cdot\left[\mathrm{H}_{2} \mathrm{O}\right]}{K_{\text {eq }}}
\end{aligned}
$$

The reaction Equation (12) takes into account the forward reaction (esterification) and the reverse reaction (hydrolysis) through the parameters $v_{\text {max,lipase,forward }}$ and $v_{\text {max,lipase,reverse. }}{ }^{32}$ Furthermore, the typical affinity constants in form of $K_{\mathrm{m}}$ and $K_{\mathrm{l}}$ values are considered for the respective substrates of the forward reaction (acid, alcohol) and the reverse reaction (ester, water). Since the concentration of the acid can reach high values as free operating parameter, excess substrate inhibition by the acid is additionally considered $\left(K^{\prime}{ }_{\text {, CAC }}\right){ }^{32}$

\section{4 | MODEL VALIDATION}

The mathematical model described in this work was developed based on experimental data from our multi-enzyme cascade reaction (Figure 1) during the first step of laboratory-scale process development. Our model aims to simulate the cinnamyl cinnamate production process in the miniplant introduced in Figure 2, thereby making timeand cost-intensive experiments for process optimization obsolete. Therefore, the model is to be used for mathematical optimization. Prior to process simulation and optimization, however, our model needs to be validated using independent experimental data from the miniplant as the consequent second step of process development. Since the developed mathematical model is designed to perform dynamic simulations, the start-up phase of the reactor setup has to be included in the validation process.

All experiments for model validation were performed in the miniplant described in Figure 2 in the previous chapter. Five hundred milliliters of a $0.1 \mathrm{M}$ potassium phosphate buffer at $\mathrm{pH} 8.0$ were used in the continuously stirred tank reactor (Figure $2 \mathrm{a}$ ), tempered to $30^{\circ} \mathrm{C}$. This device is equipped with a SpinChem ${ }^{\circledR}$ reactor, spinning at $400 \mathrm{rpm}$ and containing $21.3 \mathrm{mg}$ of immobilized $\mathrm{ADH}$ and $6.6 \mathrm{mg}$ of immobilized $\mathrm{FDH}$. Two hundred and fifty milliliters per minute are pumped within the water-based cycle through the extractive centrifuge (Figure 2c), thereby connecting the two cycles. The organic cycle consists of $500 \mathrm{ml}$ of xylene provided in the buffer tank (Figure $2 \mathrm{~b}$ ), $100 \mathrm{ml} / \mathrm{min}$ of which are pumped via the extractive centrifuge through the fixed bed reactor (Figure 2d) filled with $12.8 \mathrm{~g}$ of Novozym ${ }^{\circledR} 435$ and tempered to $60^{\circ} \mathrm{C}$. Six different experiments were performed with varying starting concentrations, to validate our mathematical model using a broad range of experimental data. Table 4 shows the supplied starting concentrations of the educts for all six experiments, as well as the achieved molar yield of $\mathrm{CCl}$ after $54 \mathrm{hr}$ of operation with respect to the CAL starting concentration, calculated according to Equation (13).

$$
Y_{\mathrm{CCl}, t}=\frac{n_{\mathrm{CCl}, t}}{n_{\mathrm{CAL}, t=0}}
$$

During the experiments, samples were taken from both phases and analyzed in a Perkin Elmer Clarus $500^{\circledR}$ (PerkinElmer Inc.) gas chromatograph equipped with a $30 \mathrm{~m}$ SLB SUPELCO ${ }^{\circledR}$ (Supelco, Inc.) column with a $0.25 \mathrm{~mm} \times 0.25 \mu \mathrm{m}$ cross section, thus generating concentration profiles of all components over time. Exemplary for our experimental results, Figure 4 shows the molar profiles of the intermediate $\mathrm{COH}$ and the final product $\mathrm{CCl}$ in the organic phase of experiment 2 as well as the corresponding simulated values using the mathematical model described in the previous chapter. The molar profiles of all other experiments are shown in the Supporting Information. The experiment shown in Figure 4 has a total duration of 80 hr: during the first $65 \mathrm{hr}$, the aqueous cycle is running without the organic cycle, allowing for a separate evaluation of the reactions as well as sufficient intermediate formation leading to a clearer concentration profile in the later connected organic cycle. 


\begin{tabular}{|llllcl|}
\hline Experiment & NADH $(\mathrm{mM})$ & $\mathrm{CAL}(\mathrm{mM})$ & Formate $(\mathrm{mM})$ & $\mathrm{CAC}(\mathrm{mM})$ & $\mathrm{Y}(\mathrm{CCl})_{54 \mathrm{~h}}(\%)$ \\
\hline 1 & 3.2 & 6.9 & 324.0 & 24.3 & 14.1 \\
\hline 2 & 3.5 & 8.8 & 328.0 & 56.3 & 24.9 \\
\hline 3 & 3.5 & 6.8 & 328.0 & 94.7 & 22.8 \\
\hline 4 & 5.0 & 6.9 & 350.0 & 64.3 & 21.6 \\
\hline 5 & 1.5 & 0.7 & 291.0 & 101.7 & 16.5 \\
\hline 6 & 0.5 & 3.1 & 97.6 & 24.3 & 15.2 \\
\hline
\end{tabular}

TABLE 4 Starting concentrations of educts and $\mathrm{CCl}$ yield for the six experiments performed in the miniplant

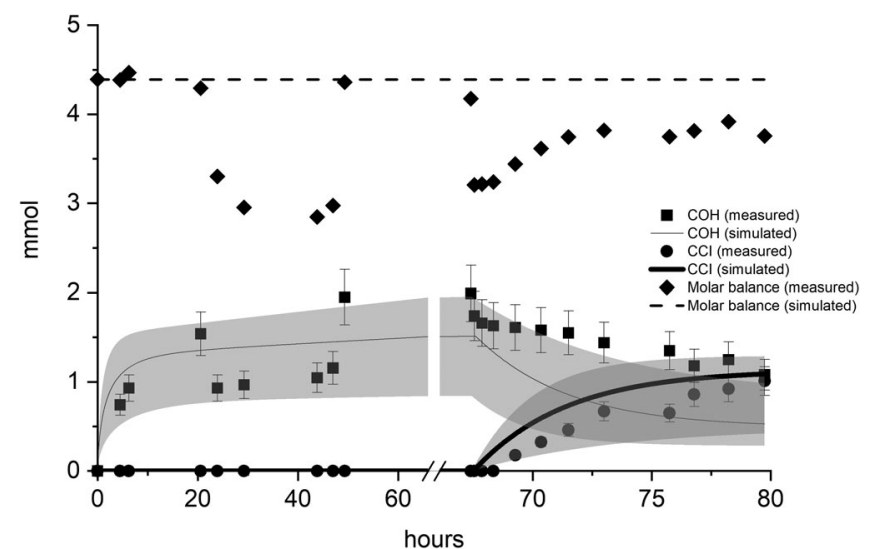

FIGURE 4 Experimental and simulated data of experiment number 2 for model validation

In Figure 4, the squares and circles indicate the measured concentrations of $\mathrm{COH}$ and $\mathrm{CCl}$ respectively. The continuous line shows the simulated values for $\mathrm{COH}$, surrounded by a shaded area which indicates molar value ranges induced by the $S D$ ranges of the kinetic parameters. The bold line indicates the simulated values for $\mathrm{CCl}$, again surrounded by a value range induced by the SDs obtained in the kinetic parameters determination. The dashed line shows the overall molar balance equation which is unchanged during the course of a simulation due to the equimolar reactions, while the experimentally measured molar balances are indicated by the diamonds. The overall molar balance includes the components CAL and CAC.

As can be seen in Figure 4, the intermediate concentration of $\mathrm{COH}$ increases for the first $65 \mathrm{hr}$ and then decreases after the organic cycle is connected and the lipase performs the esterification reaction, leading to a constant increase in $\mathrm{CCl}$. The mean deviations of the experimental values from the simulated values are 26.7 and $20.8 \%$ for $\mathrm{COH}$ and $\mathrm{CCl}$ respectively. $\mathrm{CCl}$ shows good agreements throughout the experiment, while $\mathrm{COH}$ varies toward the end of the experiment. Deviations of experimental and simulated $\mathrm{COH}$ values can also be observed during the first phase of the experiments at around 2,000 min. In both cases, these deviations can be explained with the experimentally measured overall molar balance, which does not mathematically add up during those measurements. Especially in the last $800 \mathrm{~min}$ of the experiment, the experimentally determined molar balance varies: this can be due to dead volume in the organic cycle containing xylene, leading to a dilution of the samples or precipitation of the components $\mathrm{CAL}, \mathrm{COH}$, or CAC. Potential side reactions behind such variations have not been observed. ${ }^{26}$ It shall be noted that the variations in overall molar balance are significantly smaller for the other experiments, ranging from 5.98 to $17.68 \%$, as can be seen in the Supporting Information.

Throughout all six experiments we simulated for model validation, the mean deviation reached values of $26.0 \%$ and $22.6 \%$ for $\mathrm{COH}$ and $\mathrm{CCl}$ respectively, and $11.66 \%$ for the overall molar balance, which can be traced back to the deviations of the enzymes' kinetic parameters. $^{26,33-35}$ In literature, mathematical models for such complex multienzyme processes across phase boundaries in miniplant-scale and continuous operation cannot be found to the best of our knowledge. Examples of enzyme-based process modeling and simulation exist that do not validate the model with independent experimental data, ${ }^{31,36,37}$ or their validation is based on qualitative agreement between experimental and simulated values. ${ }^{38,39}$ Few examples exist for less complex and less time intensive reaction sequences that allow for a quantitative evaluation, giving deviations in the range of $\sim 25 \%,{ }^{40}$ or of above $30 \%{ }^{41}$ for dynamic simulations. In the reactive zone filled with Novozym $^{\circledR} 435$ of a technical-scale reactive dividing wall column operated with one reaction, Egger ${ }^{42}$ observed concentration deviations between experiments and simulations of up to $20 \%$. In this work, however, an enzyme cascade with a total of three enzymatic reactions at once is investigated. Therefore, it can be stated that the simulated values throughout all six experiments presented in this work lie in good agreement with the experimental results, proving the applicability of our model to the reactor setup. Using our validated model, process optimization can now thus be conducted without the need for further experimental runs.

\section{5 | PROCESS OPTIMIZATION}

With the help of our simulation model described in the previous chapter, computational process optimization methods can now be used to mathematically optimize process conditions and find the optimal operating windows for the multi-enzyme cascade reaction sequence implemented in our miniplant. More specifically, the Institute of Process and Plant Engineering at Hamburg University of Technology has developed the multi-objective process optimization tool "Advanced Process Optimizer" (Adv:PO V0.7), which can be coupled with flow sheet simulator tools such as Aspen Custom Modeler ${ }^{\circledR}{ }^{43-45}$ The Adv: PO makes use of a genetic algorithm 17 mimicking the methods of 
biological evolution, and it has been successfully applied to various chemical and biotechnological processes. ${ }^{22,25,43-46}$ In a first step, a randomly selected set of so-called "individuals" is created to form the initial population. Each individual represents a fully parameterized setup of the miniplant process. These processes are then automatically simulated in ACM and evaluated, based on pre-defined objective functions, constraints and abort criteria. If the abort criteria are not met, a next-generation population is formed through the three genetic operators selection, mutation, and crossover. This cyclic formation of new generations is continued until a population meets the abort criteria. A graphical overview of the genetic algorithm (based on Zitzewitz ${ }^{22}$ and Ernst ${ }^{47}$ ) is provided in the Supporting Information. The implementation of this tool, together with our novel mathematical model, allows for in-depth analysis and process improvement of the multi-enzyme cascade reaction sequence to find optimal operating conditions.

During the optimization run, process variables, that is, the concentrations of each component, are varied between physically defined limits. Such constraints are determined by component solubility and by the capacity of the miniplant. Multi-objective mathematical functions are defined in order to find the optimal solutions for any experimental variable of the cascade reaction. In this paper we focus exemplarily on presenting our results for maximizing $\mathrm{CCl}$ space-time yield in steady-state operation, while at the same time minimizing the amount of the costly cofactors NADH and NAD . Such focus will broaden the single-criterion-approach of increasing product space-time yield by the economic factor of avoiding unnecessary amounts of costly substances. The objective functions $f_{1}$ and $f_{2}$ in Equations (14) and (15) represent the maximizing of $\mathrm{CCl}$ spacetime yield and the minimizing of the cofactor input. They are complemented by physical constraints. As shown in Equation (16), the concentration for each component must range within physically reasonable values. Moreover, all dimensions, flow rates, temperatures, and kinetic parameters must stay constant throughout the optimization run. Possible trivial solutions of zero are not accepted: a minimum $\mathrm{CCl}$ space-time yield of $0.1 \mathrm{mmol} /(\mathrm{L} \cdot \mathrm{hr})$ is set as a constraint for valid solutions.

$$
\begin{gathered}
\operatorname{maxf}_{1}=\max \left(\dot{n}_{\mathrm{CCl}, \text { out }}\right)=\operatorname{maxf}\left(v_{\text {eff,ADH }}, v_{\text {eff,FDH }}, v_{\text {lipase }}\right) \\
\operatorname{minf}_{2}=\min \left(n_{\text {Cofactor }}\right)=\operatorname{minf}\left(c_{\mathrm{NAD}^{+}}, c_{\mathrm{NADH}}, V\right) \\
0 \leq c_{i} \leq c_{i, \text { solubility }}
\end{gathered}
$$

This results then in a Pareto front representing a set of optimal solutions, each one being a trade-off of the objective functions whereby no other solution can satisfy both objective functions better. Exemplarily for these results, Figure 5 shows a multi-objective optimization run to increase the $\mathrm{CCl}$ space-time yield while decreasing the cofactor concentration after 50, 200, and 300 generations of the aforementioned algorithm cycles respectively: as can be seen in Figure 5, 200 generations are sufficient as no significant improvement is obtained even when increasing the generation number, thereby

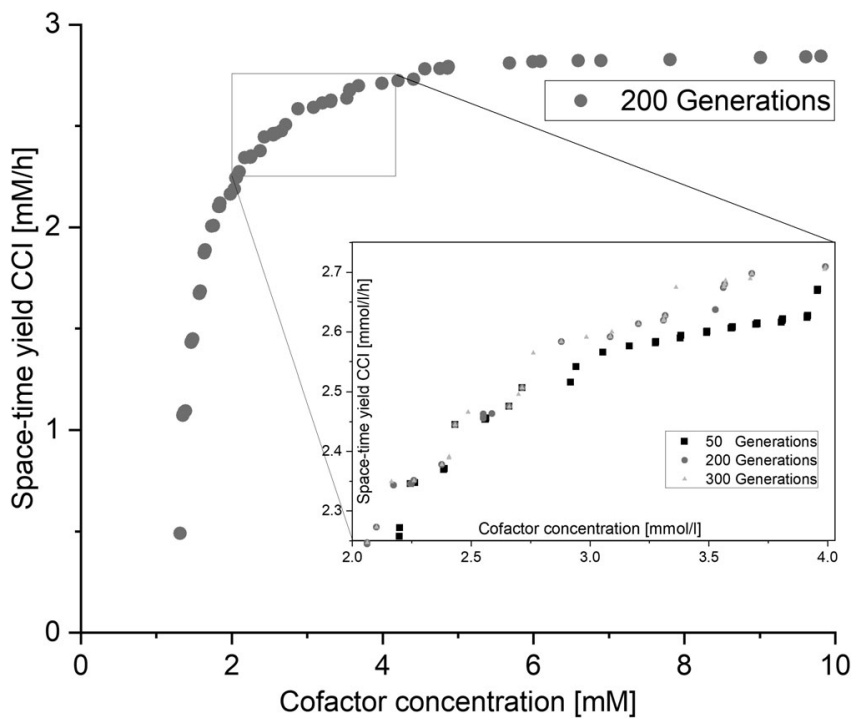

FIGURE 5 Pareto front of a multi-objective optimization of final product space-time yield and cofactor concentration in the cascade reaction sequence with varying generation numbers

proving the independency of the number of simulated generations on the optimization results.

The optimal values shown in Figure 5 vary from 1.3 to $9.8 \mathrm{mmol} / \mathrm{L}$ for cofactor concentration and $0.49 \mathrm{mmol} /(\mathrm{L} \cdot \mathrm{hr})$ to $2.84 \mathrm{mmol} /(\mathrm{L} \cdot \mathrm{hr})$ for $\mathrm{CCl}$ space-time yield respectively. Moreover, our results identified a suitable operating window, as the $\mathrm{CCl}$ spacetime yield rate significantly increases with a higher cofactor concentration. This remains true up to a value of $\sim 4.2 \mathrm{mmol} / \mathrm{L}$, after which the space-time yield difference is smaller than $1 \%$ with increasing cofactor concentration. The lower operating window frame can be set according to a usual space-time yield value of $1 \mathrm{mmol} /(\mathrm{L} \cdot \mathrm{hr})$ for industrial biotechnological processes ${ }^{48}$ and to a corresponding cofactor concentration of $1.4 \mathrm{mmol} / \mathrm{L}$, thereby framing the most promising operating window with regard to the aforementioned two objectives.

Such optimization runs can now be performed for multiple experimental conditions and objectives, allowing for a profound understanding of the multi-enzyme cascade reaction sequence and the production process of $\mathrm{CCl}$ in the miniplant without the need for costand time-intensive experiments. To the best of our knowledge, multiobjective mathematical process optimization has not yet been applied to complex multi-enzyme cascade reactions in a miniplant-scale reactor setup.

\section{6 | CONCLUSION AND OUTLOOK}

The wo rld-wide growing demand for natural flavors poses a chance for enzyme-based production processes to be implemented to specialty and fine chemicals industry. In vitro multi-enzyme cascade reactions are a promising part of such novel, enzyme-based approaches, in that they present a chance for process integration. Within our 
research group, a three-enzyme cascade reaction sequence with integrated cofactor regeneration and integrated intermediate extraction in a two-phase system has been successfully established and scaled up for application in a miniplant at the example of the ester cinnamyl cinnamate. Due to their high complexity compared to conventional chemical synthesis routes, however, such enzyme-based processes are difficult to mathematically describe. On the other hand, mathematical modeling is an important prerequisite for the industrial application of novel production processes. ${ }^{8}$

Therefore, in this contribution the authors introduce an Aspen Custom Modeler ${ }^{\circledR}$-implemented mathematical model to describe the aforementioned complex biotechnological production process for a miniplant-scale reactor setup. Here, sub-models for each thermodynamic phase and for the integrated extraction step respectively are connected through differential mass balance equations, resulting in one holistic mathematical model describing the cascade reaction. In this study, successful validation of the model with independent experimental data obtained from the miniplant is presented for the first time. Using this validated model, multi-objective mathematical optimization runs were performed with the in-house-developed optimization tool Adv:PO. As a result, the authors can now identify optimal process operating windows for any given multi-objective function within the cascade reaction. The Pareto-optimal dependency of cofactor concentration on cinnamyl cinnamate space-time yield is analyzed and shown in this work as a representative example for such optimization results, obtaining a suitable cofactor concentration range of 1.4-$4.2 \mathrm{mmol} / \mathrm{L}$.

Future research will now further investigate the optimal operating settings for the miniplant-scale production process. Specifically, integration of the product separation step will be the focus of our work: promising results for cinnamyl cinnamate separation from the product mixture were already achieved using annular chromatography. Incorporating the downstream process into the mathematical model for process optimization will show the full potential of this novel process specifically, and the benefits of applying mathematical modeling and optimization to biotechnology in general.

\section{ACKNOWLEDGMENTS}

The authors thank the Deutsche Forschungsgemeinschaft (German Research Foundation) for funding this project (DFG WA 3957/1-1 \& DFG BU 3409/1-1), and Novozymes ${ }^{\circledR}$ for the generous donation of Novozym ${ }^{\circledR} 435$.

\section{NOTATION}

$\begin{array}{ll}\text { ACM } & \text { Aspen Custom Modeler } \\ \text { ADH } & \text { alcohol dehydrogenase } \\ \text { CAC } & \text { cinnamic acid } \\ \text { CAL } & \text { cinnamyl aldehyde } \\ \mathrm{CCl} & \text { cinnamyl cinnamate } \\ \mathrm{COH} & \text { cinnamyl alcohol } \\ \mathrm{CSTR} & \text { continuously stirred tank reactor }\end{array}$

\begin{tabular}{|c|c|}
\hline $\mathrm{FDH}$ & formate dehydrogenase \\
\hline$f$ & objective function for optimization \\
\hline$f_{\text {deac }}$ & deactivation factor of FDH \\
\hline $\mathrm{hr}$ & hour \\
\hline$i$ & index referring to any component of the system \\
\hline j & index referring to any CSTR in the CSTR-cascade \\
\hline$K_{\mathrm{eq}}$ & equilibrium constant \\
\hline$K_{\mathrm{l}}$ & inhibition constant (mM) \\
\hline$K_{\mathrm{m}}$ & Michaelis-Menten constant (mM) \\
\hline $\mathrm{L}$ & liter \\
\hline $\mathrm{m}$ & mass (mg) \\
\hline$\dot{n}$ & mole flow (mmol/min) \\
\hline$n$ & mole number (mmol) \\
\hline$\dot{n}_{\text {feed }, i}$ & $\begin{array}{l}\text { feed of component } i \text { into the aqueous phase } \\
(\mathrm{mM} / \mathrm{min})\end{array}$ \\
\hline$\dot{n}_{\text {precipitation }, i}$ & $\begin{array}{l}\text { storage term in the aqueous phase of component } \\
i(\mathrm{mM} / \mathrm{min})\end{array}$ \\
\hline$\dot{n}_{\text {transfer }, i}$ & $\begin{array}{l}\text { mass transfer of component } i \text { to the organic phase } \\
(\mathrm{mM} / \mathrm{min})\end{array}$ \\
\hline$P$ & partition coefficient \\
\hline$T$ & temperature $\left({ }^{\circ} \mathrm{C}\right)$ \\
\hline$t$ & time (min) \\
\hline V & volume $\left(\mathrm{m}^{3}\right)$ \\
\hline$v$ & reaction rate $\left(\mathrm{U} / \mathrm{mg}_{\text {enzyme }}\right)$ \\
\hline$v_{\text {eff }}$ & effective reaction rate $(U)$ \\
\hline$v_{\max }$ & maximum reaction rate $\left(\mathrm{U} / \mathrm{mg}_{\text {enzyme }}\right)$ \\
\hline w & mass fraction $(\mathrm{g} / \mathrm{g})$ \\
\hline Y & yield $(\mathrm{mol} / \mathrm{mol})$ \\
\hline$\eta_{\text {eff }}$ & efficiency factor of enzyme immobilization \\
\hline$\rho$ & density $\left(\mathrm{kg} / \mathrm{m}^{3}\right)$ \\
\hline$\sigma$ & $\begin{array}{l}\text { number of CSTR reactors modeled for the fixed bed } \\
\text { reactor }\end{array}$ \\
\hline
\end{tabular}

\section{AUTHOR CONTRIBUTIONS}

Jens Johannsen: Conceptualization; data curation; formal analysis; investigation; methodology; software; supervision; validation; visualization; writing-original draft; writing-review and editing. Francesca Meyer: Conceptualization; data curation; formal analysis; investigation; methodology; software; validation; visualization; writing-original draft; writing-review and editing. Claudia Engelmann: Formal analysis; investigation; writing-review and editing. Andreas Liese: Funding acquisition; supervision; writingreview and editing. Georg Fieg: Funding acquisition; supervision; writing-review and editing. Paul Bubenheim: Formal analysis; funding acquisition; project administration; supervision; writingreview and editing. Thomas Waluga: Conceptualization; data curation; formal analysis; funding acquisition; methodology; project administration; software; supervision; validation; visualization; writing-original draft; writing-review and editing.

\section{ORCID}

Jens Johannsen (D) https://orcid.org/0000-0002-8159-890X 


\section{REFERENCES}

1. IAL Consultants. An Overview of the Global Flavours \& Fragrances Market. 11th ed. London; 2018.

2. U.S. Department of Health \& Human Services. Title 21: Food and Drugs: 21CFR501.22; 2020.

3. Johannsen J, Waluga T, Fieg G, Meyer F, Kopetz N. Process for the preparation of a fatty aldehyde. Patent LU101281.

4. Vivien F-D, Nieddu M, Befort N, Debref R, Giampietro M. The hijacking of the bioeconomy. Ecol Econ. 2019;159:189-197.

5. Kiss AA, Grievink J, Rito-Palomares M. A systems engineering perspective on process integration in industrial biotechnology. J Chem Technol Biotechnol. 2015;90(3):349-355.

6. Johannsen J, Meyer F, Fieg G, Waluga T. Process for the preparation of fatty aldehydes from renewable resources. Chem Ing Tech. 2020; 92:777-781.

7. Žnidaršič-Plazl P. The promises and the challenges of biotransformations in microflow. Biotechnol J. 2019;14(8):e1800580.

8. Woodley JM. Accelerating the implementation of biocatalysis in industry. Appl Microbiol Biotechnol. 2019;103(12):4733-4739.

9. Guterl J-K, Garbe D, Carsten J, et al. Cell-free metabolic engineering: production of chemicals by minimized reaction cascades. ChemSusChem. 2012;5(11):2165-2172.

10. Ricca E, Brucher B, Schrittwieser JH. Multi-enzymatic cascade reactions: overview and perspectives. Adv Synth Catal. 2011;353(13): 2239-2262.

11. Johannsen J, Engelmann C, Liese A, Fieg G, Bubenheim PD, Waluga T. Scale-up of a multi-enzymatic cascade reaction in a multiphase system. Chem Eng Trans. 2020;79:25-30.

12. Xue R, Woodley JM. Process technology for multi-enzymatic reaction systems. Bioresour Technol. 2012;115:183-195.

13. Kroutil W, Rueping M. Introduction to ACS catalysis virtual special issue on cascade catalysis. ACS Catal. 2014;4(6):20862087.

14. Waluga T, Scholl S. Process design aspects for reaction-integrated adsorption in multi-enzymatic catalysis*. Chem Eng Technol. 2015;38 (10):1817-1826.

15. Bruggink A, Schoevaart R, Kieboom T. Concepts of nature in organic synthesis: cascade catalysis and multistep conversions in concert. Org Process Res Dev. 2003;7(5):622-640.

16. Engelmann C, Ekambaram N, Johannsen J, et al. Enzyme immobilization on synthesized nanoporous silica particles and their application in a bi-enzymatic reaction. ChemCatChem. 2020;12:22452252.

17. Johannsen J, Engelmann C, Liese A, Fieg G, Bubenheim P, Waluga T. Multi-enzymatic cascade reactions with integrated separation in a complex 2-phase system. Paper presented at: 2019 AIChE Annual Meeting Proceedings; 2019; New York.

18. Behr A, Agar DW, Jörissen J, Vorholt AJ. Einführung in die Technische Chemie. Berlin, Heidelberg: Springer Spektrum; 2017.

19. Burdock GA. Fenaroli's Handbook of Flavor Ingredients. 6th ed. Boca Raton, Florida, USA: CRC Press; 2009.

20. Chao-Yang Hsu. Catalyst and process for production of cinnamates. US Patent 4620027A; 1986.

21. European Union. Verordnung (EG) Nr. 1334/2008; 2008.

22. Zitzewitz P, Fieg G. Multi-objective optimization superimposed model-based process design of an enzymatic hydrolysis process. AIChE J. 2017;63(6):1974-1988.

23. Egger T, Fieg G. Enzymatic catalyzed reactive dividing wall column: experiments and model validation. AIChE J. 2017;63(6):2198-2211.

24. Kuhn D, Blank LM, Schmid A, Bühler B. Systems biotechnologyrational whole-cell biocatalyst and bioprocess design. Eng Life Sci. 2010;10(5):384-397.

25. Zitzewitz P. Systematik zur modellgestützten Analyse enzymkatalysierter LLS-Synthesen auf Basis mehrkriterieller Optimierung. Herzogenrath, Germany: Shaker; 2019.
26. Engelmann C, Johannsen J, Waluga T, Fieg G, Liese A, Bubenheim P. A multi-enzyme cascade for the production of high-value aromatic compounds. Catalysts. 2020;10:1216.

27. Masuda Y, Kugimiya S-i, Murai K, Hayashi A, Kato K. Enhancement of activity and stability of the formaldehyde dehydrogenase by immobilizing onto phenyl-functionalized mesoporous silica. Colloids Surf B Biointerfaces. 2013;101:26-33.

28. Lott JA. Practical problems in clinical enzymology. CRC Crit Rev Clin Lab Sci. 1977;8(4):277-301.

29. Petrat F, Bramey T, Kirsch M, Kerkweg U, de Groot H. Enhanced oxidation of $\mathrm{NAD}(\mathrm{P}) \mathrm{H}$ by oxidants in the presence of dehydrogenases but no evidence for a superoxide-propagated chain oxidation of the bound coenzymes. Free Radic Res. 2006;40(8): 857-863.

30. Hikosaka K, Kim J, Kajita M, Kanayama A, Miyamoto Y. Platinum nanoparticles have an activity similar to mitochondrial NADH:ubiquinone oxidoreductase. Colloids Surf B Biointerfaces. 2008;66(2): 195-200.

31. Waluga T, Zein M, Jördening H-J, Scholl S. Simulation der reaktionsintegrierten Adsorption von trienzymatisch produzierter Laminaribiose. Chem Ing Tech. 2014;86(1-2):119-128.

32. Bisswanger H. Enzyme Kinetics: Principles and Methods. Wiley-VCH; 2017.

33. Erhardt FA, Stammen S, Jördening H-J. Production, characterization and (co-)immobilization of dextranase from Penicillium aculeatum. Biotechnol Lett. 2008;30(6):1069-1073.

34. Šalić $A$, Ivanković $M$, Ferk $E$, Zelić B. ADH based NAD + regeneration in a microreactor. J Chem Technol Biotechnol. 2013; 88(9):1721-1729.

35. Grosch J-H, Wagner D, Knaup N, Keil T, Spieß AC. Influence of the experimental setup on the determination of enzyme kinetic parameters. Biotechnol Prog. 2017;33(1):87-95.

36. Ardao I, Zeng A-P. In silico evaluation of a complex multi-enzymatic system using one-pot and modular approaches: application to the high-yield production of hydrogen from a synthetic metabolic pathway. Chem Eng Sci. 2013;87:183-193.

37. Chen BH, Baganz F, Woodley JM. Modelling and optimisation of a transketolase-mediated carbon-carbon bond formation reaction. Chem Eng Sci. 2007;62(12):3178-3184

38. Ricca E, Calabrò V, Curcio S, lorio G. Optimization of inulin hydrolysis by inulinase accounting for enzyme time- and temperaturedependent deactivation. Biochem Eng J. 2009;48(1):81-86.

39. Zimmermann V, Masuck I, Kragl U. Reactive extraction of $\mathrm{N}$-acetylneuraminic acid-kinetic model and simulation of integrated product removal. Sep Purif Technol. 2008;63(1): 129-137.

40. Takors R. Model-based analysis and optimization of an ISPR approach using reactive extraction for pilot-scale L-phenylalanine production. Biotechnol Prog. 2004;20(1):57-64.

41. Zimmermann V, Hennemann H-G, Daussmann T, Kragl U. Modelling the reaction course of $\mathrm{N}$-acetylneuraminic acid synthesis from $\mathrm{N}$-acetyl-D-glucosamine-new strategies for the optimisation of neuraminic acid synthesis. Appl Microbiol Biotechnol. 2007;76(3): 597-605.

42. Egger T. Prozessverhalten reaktiver Trennwandkolonnen mit enzymatischem Katalysator. Herzogenrath, Germany: Shaker; 2019.

43. Ernst P, Zimmermann K, Fieg G. Multi-objective optimization-tool for the universal application in chemical process design. Chem Eng Technol. 2017;40(10):1867-1875.

44. Zimmermann K, Fieg G. Development of a diversity-preserving strategy for the Pareto optimization in chemical process design. Chem Ing Tech. 2017;89(10):1297-1305.

45. Zimmermann K, Fieg G. Global optimization of superstructures and decision support via a universally applicable optimization tool. Paper presented at: 13th International Symposium on Process Systems 
Engineering (PSE 2018). Computer Aided Chemical Engineering. Elsevier; 2018:763-768.

46. Zitzewitz P, Fieg G. New laboratory setup for the experimental analysis of a heterogeneous enzymatic hydrolysis with continuous liquidliquid phase separation. Ind Eng Chem Res. 2014;53(40):1559015599.

47. Ernst P. Entwicklung und Anwendung eines innovativen Werkzeugs für die mehrkriterielle Optimierung verfahrenstechnischer Prozesse. 1st ed. Herzogenrath, Germany: Shaker; 2014.

48. Enfors S-O, Häggström L. Bioprocess Technology: Fundamentals and Applications. Stockholm, Sweden: Royal Institute of Technology; 2000.

\section{SUPPORTING INFORMATION}

Additional supporting information may be found online in the Supporting Information section at the end of this article.

How to cite this article: Johannsen J, Meyer F, Engelmann C, et al. Multi-enzyme cascade reaction in a miniplant two-phasesystem: Model validation and mathematical optimization.

AIChE J. 2021;67:e17158. https://doi.org/10.1002/aic.17158 